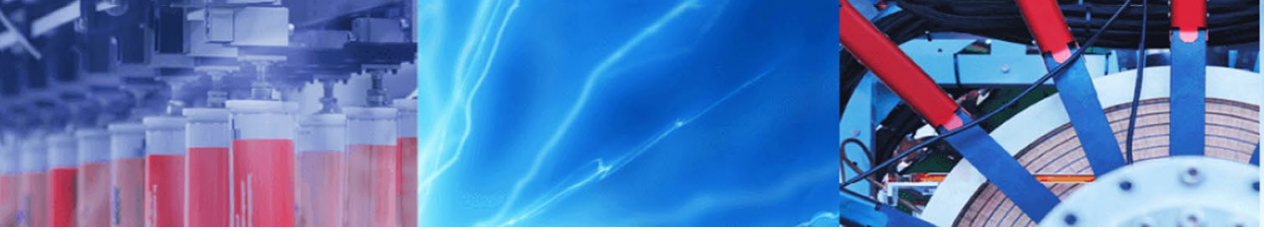

Research Article

\title{
Investigating forest fragmentation through earth observation datasets and metric analysis in the tropical rainforest area
}

\author{
Osaka Ruandache Pyngrope ${ }^{1} \cdot$ Mukesh Kumar $^{1}$ (1) $\cdot$ Rocky Pebam $^{2} \cdot$ Sudhir Kumar Singh ${ }^{3} \cdot$ Arnab Kundu $^{4}$. \\ Deepak Lal ${ }^{1}$
}

Received: 26 October 2020 / Accepted: 3 June 2021

Published online: 19 June 2021

(c) The Author(s) 2021 OPEN

\begin{abstract}
Extensive mining operations, deforestation, jhumming, and soil erosion coupled with population stress in the study area have put an adverse effect on its forest resources. This study investigates the transition in forest cover classes and its fragmentation in the Jaiñtia Hills District of Meghalaya (India). Satellite data (multispectral images from Landsat 5 and 8) for 1995, 2001, 2007, and 2015 were classified using the supervised classification method. Landscape metrics from the classified images were calculated using FRAGSTATS. The overall accuracy of classification was found to be $87.50 \%$ (1995), 87.50\% (2001), 85.00\% (2007) and 91.67\% (2015), respectively. The results revealed an increase in dense forest with an increase in the patch number from 1995 to 2007. Additionally, a decrease in non-forest cover with an increase in the number of patches from 2001 to 2015 was observed which further suggests fragmentation. It has been reported that $8.13 \%$ of the dense forest increased and $19.47 \%$ of non-forested areas decreased during the study period. Overall, this study highlights the changes in the distribution of forest area which could aid policy makers to adopt appropriate forest conservation strategies.
\end{abstract}

Keywords Forest cover · FRAGSTATS · Forest fragmentation · Class metrics · Deforestation · Soil erosion · Jaiñtia Hills (India)

\section{Introduction}

Fragmentation can be defined as a division of the landscape into smaller isolated patches which decrease the natural habitat in a landscape. Loggers, commercial cultivators, settlement planners, infrastructure developers, and expansion in the population are some of the destructive trends maximizing forest fragmentation at an alarming rate [1]. These aforementioned factors severely expose the forested area leading to vulnerability of wildlife species as well as disturbing the entire forest ecosystem.

Mining operations can also contribute to forest fragmentation which is apparent in many regions of India including the state of Meghalaya. Meghalaya possesses huge reserves of various minerals including coal, limestone, kaolin, clay, granite, glass-sand, uranium, etc. Overexploitation of such resources, e.g. extensive coal mining [2] has led to a drastic change in the land use/land cover (LULC) of the state.

Mukesh Kumar, mukeshkumar.fo@gmail.com; Osaka Ruandache Pyngrope, osapyngrope26@gmail.com; Rocky Pebam, rocky.pebam@gmail.com; Sudhir Kumar Singh, sudhirinjnu@gmail.com; Arnab Kundu, arnknd@gmail.com; Deepak Lal, deepakl@ shiats.edu.in | 1 Centre for Geospatial Technologies, Sam Higginbottom University of Agriculture, Technology and Sciences, Prayagraj 211007, Uttar Pradesh, India. ${ }^{2}$ North Eastern Space Applications Centre, Umïam 793103, Meghalaya, India. ${ }^{3} \mathrm{~K}$. Banerjee Centre of Atmospheric and Ocean Studies, Nehru Science Centre, IIDS, University of Allahabad, Prayagraj 211002, Uttar Pradesh, India. ${ }^{4}$ Department of Geo-Informatics, P.R.M.S. Mahavidyalaya, Bankura University, Bankura 722150, West Bengal, India. 
The district of Jaiñtia Hills is among the most adversely affected area of the state of Meghalaya in regard to forest fragmentation resulting from coal mining. Extraction of coal is carried out by the primitive method known as rat hole mining. Major coal-bearing areas in this district are Sutnga, Shkentalang, Sohkymphor, Lakadong, Ladrymbai, Bapung, Khliehriat, Musiang Lamare, Ïlooksi, and Jaraiñ [3].

Use of technology along with appropriate policies is need of the hour for assessing, inventorying, and restricting over-exploitation of minerals towards conserving the forest ecosystem. In the last two decades, integration of remote sensing (RS) data with geographic information systems (GIS) made noteworthy contributions towards the assessment of spatial-temporal patterns and processes of forest ecosystems in criteria-based decision-making and selection of the optimal alternative $[4,5]$. Numerous researchers have developed metrics to measure multiple aspects of landscape patterns [6-12]. FRAGSTATS 4.2.1 has emerged as one of the most promising tools for performing spatial analysis to compute the disturbance index [12].

Considering the aforementioned issues with regard to forest fragmentation particularly in the district of Jaiñtia Hills, this study aims to analyse the spatial and temporal pattern of forest fragmentation during the past two decades using FRAGSTATS model along with RS and GIS techniques.

\section{Materials and methods}

\subsection{Study area}

The study area (district of Jaiñtia Hills) consists of the eastern part of Meghalaya with a geographic area of $3819 \mathrm{~km}^{2}$. It is situated between east longitude $91.59^{\circ}$ and $92.45^{\circ}$ and between north latitude $25.3^{\circ}$ and $25.45^{\circ}$ (Fig. 1). It covers around $17 \%$ of the total area of Meghalaya State. The elevation of the district ranges between $1050 \mathrm{~m}$ and $1350 \mathrm{~m}$. Jaiñtia Hills has a comparably flatter topography with a mild gradient. The district has a forest area of $1540.6 \mathrm{~km}^{2}$, i.e. about $40 \%$ of the total geographic area [13].

Study area is enclosed on the north and east by the state of Assam, on the south by Bangladesh, and on the west by the East Khasi Hills District of Meghalaya. Jaiñtia Hills District is divided into five blocks consisting of Amlarem, Thadlaskeiñ, Laskeiñ, Khliehriat, and Saipung [14]. Amlarem is the smallest block in the district with a population of 43,844 , whereas Thadlaskeiñ is the biggest block with a population of 137,939 [15]. Myntdu is one of the major water bodies of the study area (Appendix 1). The drainage pattern of the study area is sub-parallel to parallel. It is being controlled by joints and faults as indicated by the straight courses of the rivers and streams with deep gorges.

\subsection{Data used and methodology}

Satellite images from Landsat 5 and 8 for the period 1995-2015 were used towards spatio-temporal analysis of Jaiñtia Hills District, Meghalaya. The study area is covered by path 136 and row 42/43 of Landsat images. Details of the satellite images utilized in the present study are provided in Appendix 2. The Landsat images utilized in the present study were acquired for the month of March to minimize the significant exposure of the sun angle on the northern slope. Top of atmospheric (ToA) calibration was performed to obtain the reflectance values on a scale of 0 to 1 . Many studies have used remote sensing data based on classification algorithms for the extraction of forest land cover information $[16,17]$. Satellite images were classified using the supervised classification method with a maximum likelihood algorithm [18-21]. Major land cover classes of the study area were categorized into dense forest, open forest, scrub forest, and non-forest (the wastelands, built-up, croplands, and water bodies were clubbed in the non-forest category). After that, post-classification techniques were used which help in removing noises and improve the quality of the classified image. It was achieved by sieve, clump, elimination, and majority filter tools which has enhanced the output image quality before comparing two different time period images. A description of various land cover classes is provided in Appendix 3.

Change analysis was performed to assess changes in the past decade of 1995-2015. A colour coded scheme was adopted to delineate positive change with green colour (non-forest to forest change) as well as negative change with red colour (forest to non-forest change). A change matrix for different land cover classes was calculated. The positive and negative changes were also identified at block-level in the study area. Lastly, the data were processed using FRAGSTATS 4.2.1 software to analyse the spatial metrics and comprehend the fragmentation of various land covers. The methodology followed in the present study is summarized in Fig. 2.

\subsection{Computation of landscape metrics}

Landscape ecology is the interaction between various elements of a landscape, and how these patterns/interactions change over time [22-25]. Landscape metrics explores site variability and the effects of fragmentation. Several studies have shown that landscape metrics have the potential for analysing the spatial arrangement of LULC and monitoring the spatio-temporal changes [26-32]. However, a selection of appropriate key approaches must be done in 
Fig. 1 Study area map: Jaiñtia Hills, Meghalaya (India)

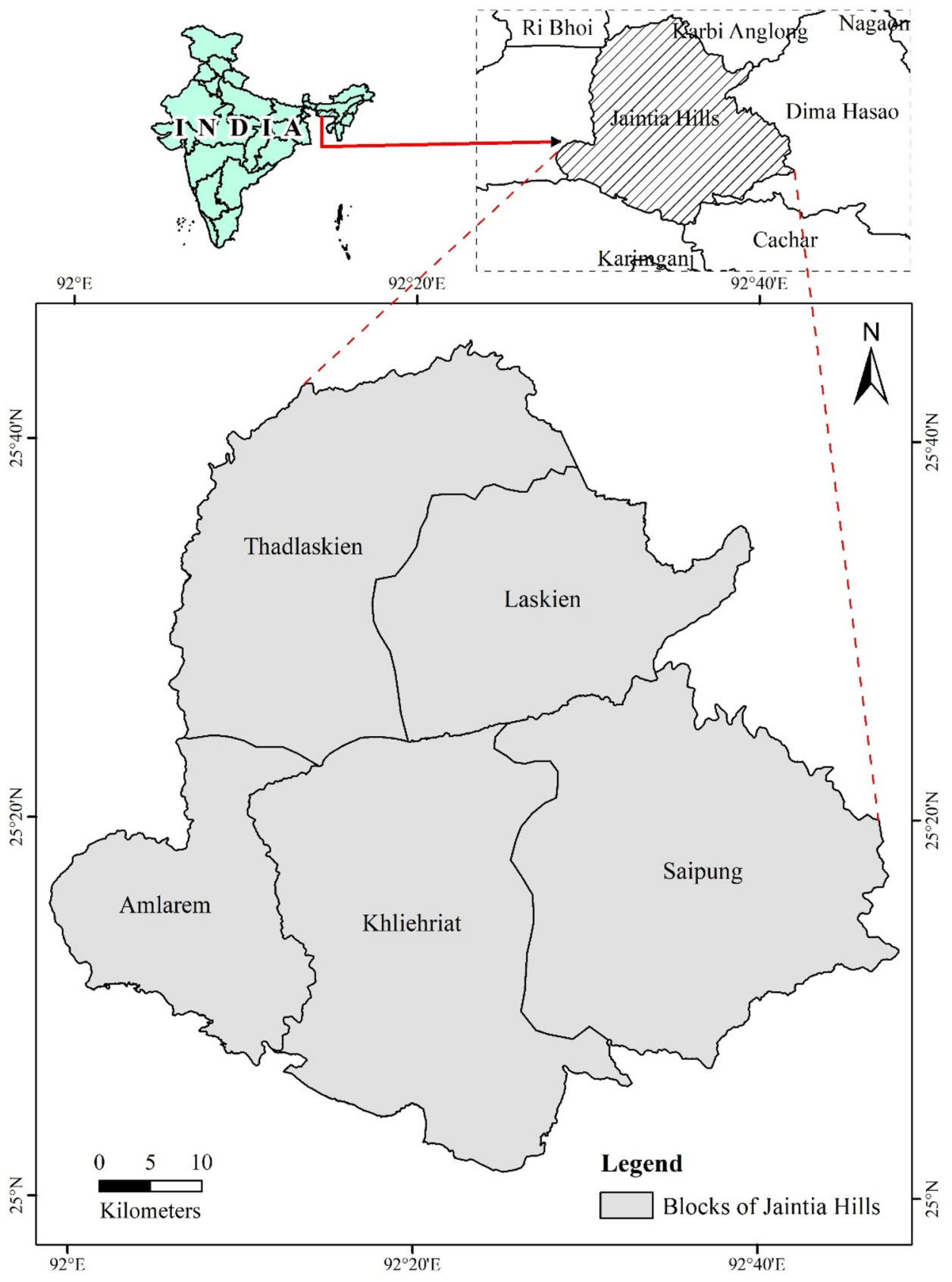

order to avoid redundant information of the landscape metrics [26, 33-37]. A set of key metrics that can be used to characterize landscape structure includes Class Area (CA), Percentage of Landscape (PLAND), Number of Patches (NP), Patch Density (PD), Largest Patch Index (LPI), Total Edge (TE), Edge Density (ED), Largest Shape index (LSI), Inter-juxtaposition Index (IJI) and MESH. Quantification of landscape habitat connectivity can be done on various spatial levels based on patch, class, and landscape [38] (Appendix 4). In this study, the analysis of fragmentation was focused at the class level. To analyse the process of fragmentation, the LULC raster maps were subjected to
FRAGSTATS 4.2.1 [39, 40]. Ten parameters underclass metrics that included CA, PLAND, NP, PD, LPI, TE, ED, LSI, IJI, and $\mathrm{MESH}$ were selected using 8-neighbouring rule [36, 41-44] (Appendix 5). This gives the required flexibility to assess the landscape pattern and landscape connectivity [45]. PLAND, NP, PD, LPI, TE, and ED delineate amply the extent of fragmentation $[26,35,46]$. NP indicates the rate of loss denoting the information about the area, shape, or distribution of the fragments. The density of patches is computed using PD metrics, ultimately indicating the level of fragmentation. IJI is used for identifying the intermixing of different patch types irregularly. 
Fig. 2 Flowchart of methodology

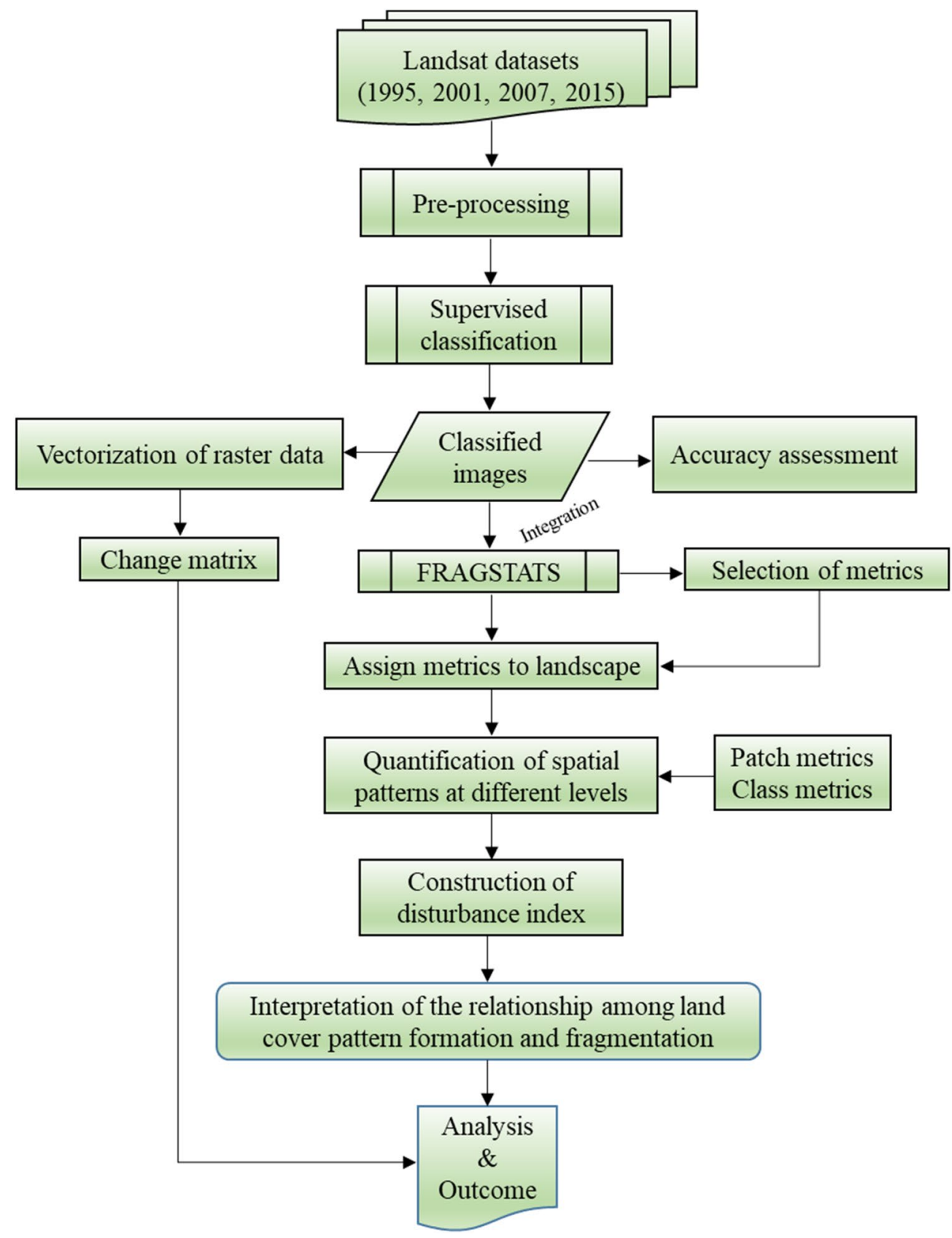

\section{Results and discussion}

\subsection{Accuracy assessment}

Accuracy assessment of land cover maps (1995, 2001, 2007, and 2015) was performed to obtain user accuracy, producer accuracy, overall classification accuracy, and kappa statistics using equalized random sampling strategy [47]. Additionally, 50 ground control points were utilized for comparing the accuracy of land cover maps. The overall classification accuracy was found to be 87.50, 87.50, 85.00, and $91.67 \%$ for $1995,2001,2007$, and 2015 , respectively (Table 1).
Table 1 Accuracy assessment of supervised classification method

\begin{tabular}{lll}
\hline Year-wise analysis & Classification accuracy $(\%)$ & Kappa $(K \wedge)$ \\
\hline 1995 & 87.50 & 0.8333 \\
2001 & 87.50 & 0.8333 \\
2007 & 85.00 & 0.7887 \\
2015 & 91.67 & 0.8889 \\
\hline
\end{tabular}

\subsection{Spatial extent of forest cover classes (1995- 2015)}

Forest cover change throughout the study period is presented in Table 2 and Fig. 3, respectively. Based on 
temporal forest change analysis for the period 1995-2001, an increase in dense forest cover has been observed which is about $13.18 \%$ (764.98 to $1269.64 \mathrm{~km}^{2}$ ). Similarly, during the period 2001-2007, about 1.5\% (1269.64 to $1327.23 \mathrm{~km}^{2}$ ) dense forest has increased. However, for the year 2007-2015, dense forest cover declined considerably to $250.63 \mathrm{~km}^{2}$ (1327.23 to $1076.60 \mathrm{~km}^{2}$ ) which is $6.55 \%$. The maximum area (34.64\%) for dense forest was observed in the year 2007. However, in the past 20 years, approximately $19.45 \%$ of the area lost its forest cover (Fig. 3). Approximately $9.79 \%$ (928.27 to $553.21 \mathrm{~km}^{2}$ ) of the open forest has decreased for the period 1995-2001. Moreover, a decrease of approximately $6.18 \%$ (553.21 to $790.16 \mathrm{~km}^{2}$ ) has been observed for the period 2001 to 2007. However, an increase of $14.75 \%$ (790.16 to $\left.1355.20 \mathrm{~km}^{2}\right)$ in the open forest was observed during 2007-2015.

Scrub forest indicated an overall decrease in its area during 1995-2007 with a slightly abrupt increase (0.48\%) between 2007 and 2015 covering an area of $18.52 \mathrm{~km}^{2}$ (9.09 to $27.61 \mathrm{~km}^{2}$ ). The non-forest area exhibited a decreasing trend from 1995 with an area of $2118.06 \mathrm{~km}^{2}$ (55.28\%) to $1989.44 \mathrm{~km}^{2}$ (51.93\%) in 2001 followed by a spontaneous decline of $1704.68 \mathrm{~km}^{2}(44.49 \%)$ in 2007 and $1372.18 \mathrm{~km}^{2}$ (35.81\%) in the year 2015 (Table 2).

Table 2 summarizes the changes in forest cover. Increase in dense forest apparent between 1995 and 2007 can be attributed to the intensification of commercial plantations such as Areca nut (Areca catechu), bamboo (Bambusa sp.), banana (Musa paradisiaca), black pepper (Piper nigrum), and canes (Calamus sp.) cultivated with Acquilaria [48]. Betel leaf is an important cash crop in Meghalaya with high demands across local, national and international markets which are planted in lower altitude, i.e. low-lying area of Khliehriat block near Bangladesh border. Secondly, it may be due to plantation via afforestation programmes under the social forestry division. Three forest divisions of Khasi, Jaiñtia, and Garo Hills were under programmes such as social forestry where the forest department carried out plantation in more than $1645 \mathrm{~km}^{2}$ area [49]. Although [50] reported a decrease in a dense forest in the study area, the result obtained for this area is same as statistics produced by the Forest Survey of India (FSI) where forest area increased from 1995 to 2007 with a slight decrease in forest cover from 2007 to 2015 [51].In general, during 1990-2000, India's forest cover increased at the rate of $0.22 \%$ per year and $0.46 \%$ during $2000-2010$. As reported by the India State of Forest Report (ISFR), India's forest cover has increased by $2000 \mathrm{~km}^{2}$ [52]. Increase in forest area was also observed between 2015 and 2017 in parts of the southern states of Karnataka, Kerala, and Andhra Pradesh due to plantation activities [53]. It was reported that from the year 2007 onwards larger scale of limestone mining, and production activity was started by the cement factories in Jaiñtia Hills [54]. This could be among the
Table 2 Temporal land cover change analysis for different years of Jaiñtia Hills in terms of area $\left(\mathrm{km}^{2}\right)$

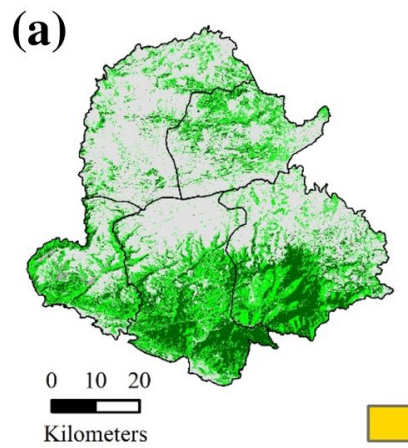

\begin{tabular}{|c|c|c|c|c|c|c|c|c|}
\hline \multirow[t]{2}{*}{ Land cover classes } & \multicolumn{2}{|l|}{1995} & \multicolumn{2}{|l|}{2001} & \multicolumn{2}{|l|}{2007} & \multicolumn{2}{|l|}{2015} \\
\hline & $\begin{array}{l}\text { Area } \\
\left(\mathrm{km}^{2}\right)\end{array}$ & $\begin{array}{l}\text { Area } \\
(\%)\end{array}$ & $\begin{array}{l}\text { Area } \\
\left(\mathrm{km}^{2}\right)\end{array}$ & $\begin{array}{l}\text { Area } \\
(\%)\end{array}$ & $\begin{array}{l}\text { Area } \\
\left(\mathrm{km}^{2}\right)\end{array}$ & $\begin{array}{l}\text { Area } \\
(\%)\end{array}$ & $\begin{array}{l}\text { Area } \\
\left(\mathrm{km}^{2}\right)\end{array}$ & $\begin{array}{l}\text { Area } \\
(\%)\end{array}$ \\
\hline Scrub forest & 20.35 & 0.53 & 18.86 & 0.49 & 9.09 & 0.24 & 27.61 & 0.72 \\
\hline Open forest & 928.27 & 24.23 & 553.21 & 14.44 & 790.16 & 20.62 & 1355.20 & 35.37 \\
\hline Dense & 764.98 & 19.96 & 1269.64 & 33.14 & 1327.23 & 34.64 & 1076.60 & 28.09 \\
\hline Non-forest & 2118.06 & 55.28 & 1989.44 & 51.93 & 1704.68 & 44.49 & 1372.18 & 35.81 \\
\hline Total & 3831.66 & 100 & 3831.16 & 100 & 3831.16 & 100 & 3831.59 & 100 \\
\hline
\end{tabular}

(b)

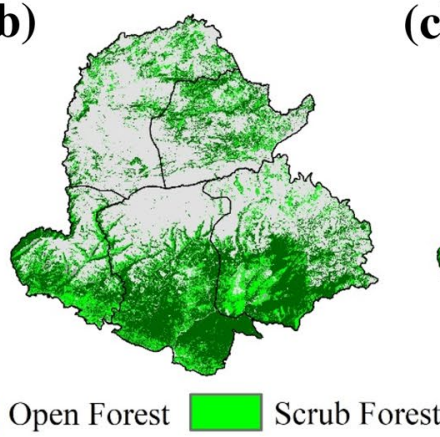

(c)

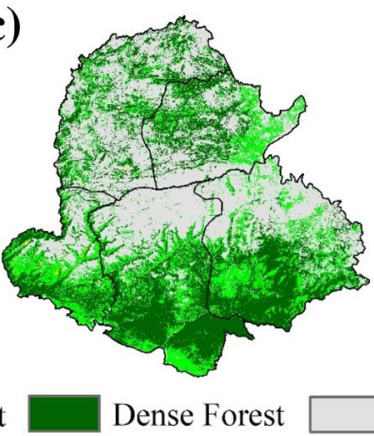

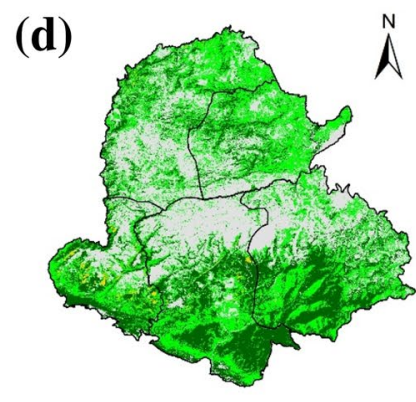

Non Forest

Fig. 3 Classified imageries for the years (a) 1995, (b) 2001, (c) 2007, and (d) 2015 using a supervised classification method 
probable reasons for the decrease in dense forest cover from 2007 to 2015. Such activities create canopy gaps resulting in the spread of invasive exotic species which adversely affects faunal species of the area. Mining activities leave significant ecological, economic and social footprints much beyond the physical boundaries of mines by disrupting continuous forest patches $[55,56]$.

\subsection{Matrix of land cover change}

The square transition matrix gives insights into the degree of change of classes when the two images acquired in different years are directly compared to assess increase and decrease in classes. In this study, a change matrix table was generated by the intersection of two datasets viz., 1995-2001, 2001-2007, 2007-2015, and 1995-2015, respectively. The results were summarized using tables and figures that aided in the comparison and interpretation of the results for the area and its block.

\subsubsection{LULC changes (1995-2001)}

Land cover change matrix using the classified data for the years 1995 and 2001 is presented in Table 3. It is apparent that the total area $\left(764.98 \mathrm{~km}^{2}\right)$ of dense forest during $1995-2001$ has been converted to open forest $\left(52.54 \mathrm{~km}^{2}\right)$, scrub forest $\left(0.24 \mathrm{~km}^{2}\right)$, and non-forest area $\left(36.31 \mathrm{~km}^{2}\right)$ ultimately reducing the dense forest area to $675.90 \mathrm{~km}^{2}$. In case of open forest, a large portion of its area got converted into dense forest $\left(428.84 \mathrm{~km}^{2}\right)$, followed by non-forest $\left(136.64 \mathrm{~km}^{2}\right)$ and scrub forest $\left(9.13 \mathrm{~km}^{2}\right)$. This conversion reduced the open forest area from 928.27 to $428.84 \mathrm{~km}^{2}$. A reduction in scrub forest area from 20.35 to $6.99 \mathrm{~km}^{2}$ was also apparent where $8.70 \mathrm{~km}^{2}$ of its area got converted into open forest, $2.56 \mathrm{~km}^{2}$ to non-forest and 2.10 $\mathrm{km}^{2}$ to dense forest, contribution of $162.94 \mathrm{~km}^{2}$ from nonforest and $2.10 \mathrm{~km}^{2}$ of scrub forest which got converted to the dense forest adding up its area to $1269.77 \mathrm{~km}^{2}$. The diagonal axis of the land cover change matrix represents no changing area. The change category (non-forest to forest and forest to non-forest) is presented in Fig. 4.

\subsubsection{LULC changes (2001-2007)}

The land cover change matrix was analysed using the classified thematic output for the years 2001 and 2007. It is apparent that out of the total dense forest area of $1269.64,935.44 \mathrm{~km}^{2}(73.68 \%)$ of the dense forest was intact (Table 4). A large area of $271.34 \mathrm{~km}^{2}(21.37 \%)$ has been converted to open forest, $0.27 \mathrm{~km}^{2}$ to scrub forest, and $62.59 \mathrm{~km}^{2}$ (4.9\%) to non-forest. During this period, it was also observed that $210.36 \mathrm{~km}^{2}$ of non-forest area followed by $178.08 \mathrm{~km}^{2}$ of open forest area and $3.35 \mathrm{~km}^{2}$ area of scrub forest area converted to the dense forest area. Therefore, the total dense forest area gained during 2001-2007 was $57.59 \mathrm{~km}^{2}$, an increase from 1269.64 to $1327.23 \mathrm{~km}^{2}$. The area under the open forest category increased to $790.16 \mathrm{~km}^{2}$ (20.62\%). Scrub forest area reduced to $9.09 \mathrm{~km}^{2}(0.24 \%)$ and non-forest reduced to $1704.69 \mathrm{~km}^{2}$ (44.49\%). The change category (non-forest to forest and forest to non-forest) is presented in Fig. 5.

\subsubsection{LULC changes (2007-2015)}

The land cover change matrix was analysed using the classified thematic output for the period 2007-2015. It is apparent that out of the total dense forest area of $1327.68,779.88 \mathrm{~km}^{2}(73.68 \%)$ of the dense forest was undisturbed (Table 5). However, its large area expanding to $468.62 \mathrm{~km}^{2}$ (35.29\%) got converted to open forest, $4.51 \mathrm{~km}^{2}$ to scrub forest, and $74.67 \mathrm{~km}^{2}(4.9 \%)$ to non-forest, respectively. During this period, it was also observed that about $64.45 \mathrm{~km}^{2}$ of non-forest, $231.97 \mathrm{~km}^{2}$ of open forest, and $0.30 \mathrm{~km}^{2}$ area of scrub forest got converted to dense forest area (Fig. 6). Overall, a decrease of $251.09 \mathrm{~km}^{2}$ area was apparent in dense forest during 2007-2015. Area under open forest and scrub forest categories increased from 790.61 to $1355.20 \mathrm{~km}^{2}$ and 9.08 to $27.61 \mathrm{~km}^{2}$, respectively. However, a decrease from 1704.23 to $1372.18 \mathrm{~km}^{2}$ in the non-forest area was apparent during this period (Fig. 7)
Table 3 Change matrix on land cover class between the year 1995 and 2001

\begin{tabular}{|c|c|c|c|c|c|}
\hline \multirow{2}{*}{$\begin{array}{l}\text { Land cover } \\
\text { categories }\end{array}$} & \multicolumn{5}{|c|}{1995 --or } \\
\hline & Non-forest & Dense forest & Open forest & Scrub forest & Total \\
\hline \multicolumn{6}{|c|}{2001 ---------------> } \\
\hline Non-forest & 1813.75 & 162.94 & 138.89 & 2.48 & 2118.06 \\
\hline Dense forest & 36.31 & 675.90 & 52.54 & 0.24 & 764.98 \\
\hline Open forest & 136.64 & 428.84 & 353.66 & 9.13 & 928.27 \\
\hline Scrub forest & 2.56 & 2.10 & 8.70 & 6.99 & 20.35 \\
\hline Total & 1989.26 & 1269.77 & 553.78 & 18.84 & 3831.66 \\
\hline
\end{tabular}



map for the year 1995 to 2001
Fig. 4 Change in forest class

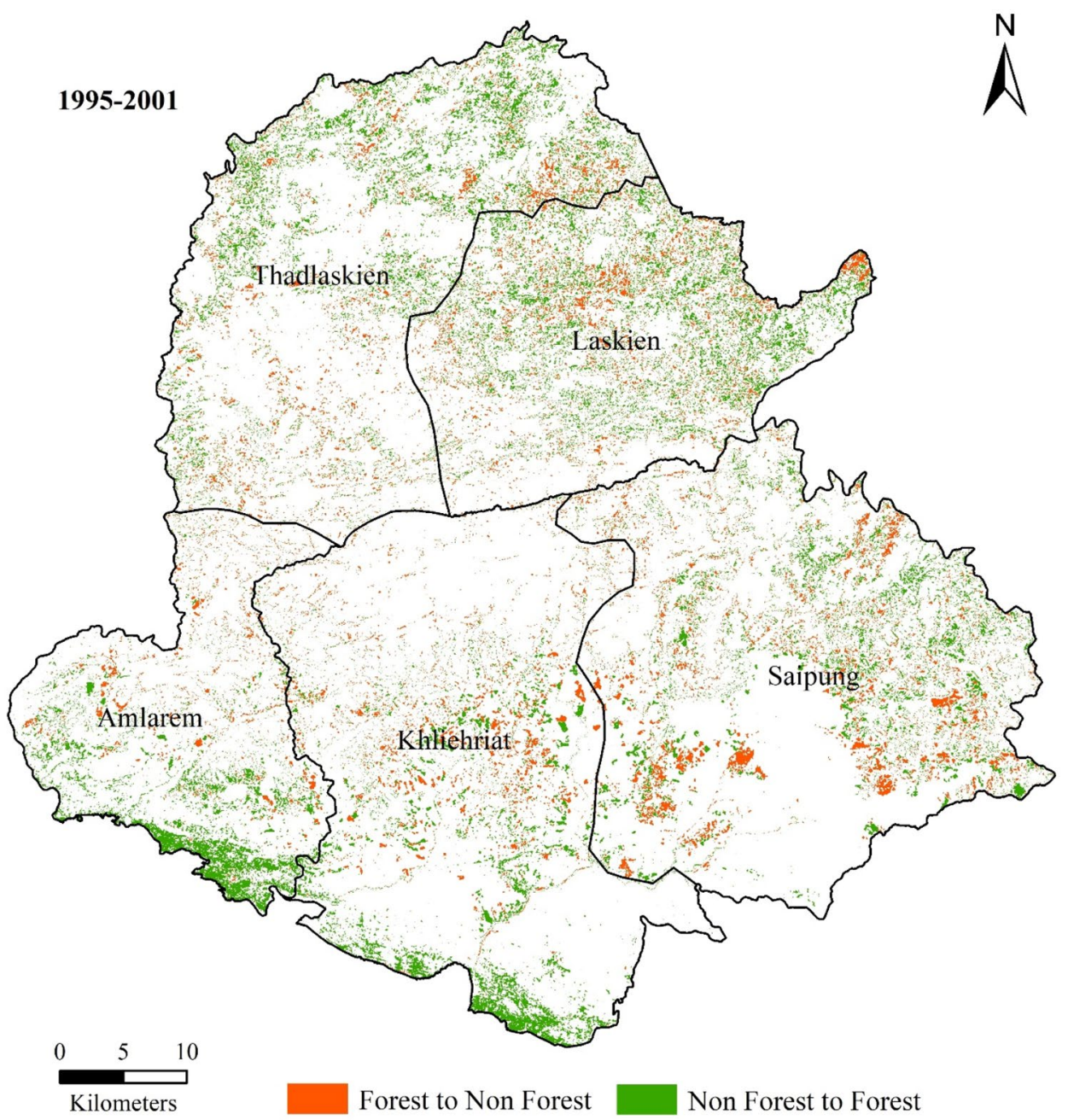

Table 4 Change matrix on land cover class between the year 2001 and 2007

\begin{tabular}{lccccr}
\hline Land cover categories & \multicolumn{2}{l}{2001 ----------------> } & & \\
\cline { 2 - 6 } & Non-forest & Dense forest & Open forest & Scrub forest & Total \\
\hline 2007 ------------> & & & & & \\
Non-forest & 1583.46 & 210.36 & 191.42 & 4.20 & 1989.45 \\
Dense forest & 62.59 & 935.44 & 271.34 & 0.27 & 1269.64 \\
Open forest & 57.91 & 178.08 & 316.00 & 1.24 & 553.21 \\
Scrub forest & 0.73 & 3.35 & 11.40 & 3.38 & 18.86 \\
Total & 1704.69 & 1327.23 & 790.16 & 9.09 & 3831.16 \\
\hline
\end{tabular}

\subsubsection{LULC changes (1995-2015)}

It is apparent that during $1995-2015,2118.36 \mathrm{~km}^{2}$ area of the non-forest area reduced to $1372.97 \mathrm{~km}^{2}$ and got converted to various other classes including dense forest, open forest and scrub forest. During the same period the dense forest increased from $764.91 \mathrm{~km}^{2}$ to $1076.19 \mathrm{~km}^{2}$. Maximum contribution in the increase in dense forest area in this period came from open forest that contributed
$301.90 \mathrm{~km}^{2}$. The scrub forest had an area of $20.35 \mathrm{~km}^{2}$ which got increased to $27.61 \mathrm{~km}^{2}$ during this period. The non-forest area conversion into open forest area apparent during this period can be attributed to plantation in the wastelands and scrublands which ultimately contributed to an increase in the open forest area (Table 6). 

map between 2001 and 2007
Fig. 5 Change in forest class

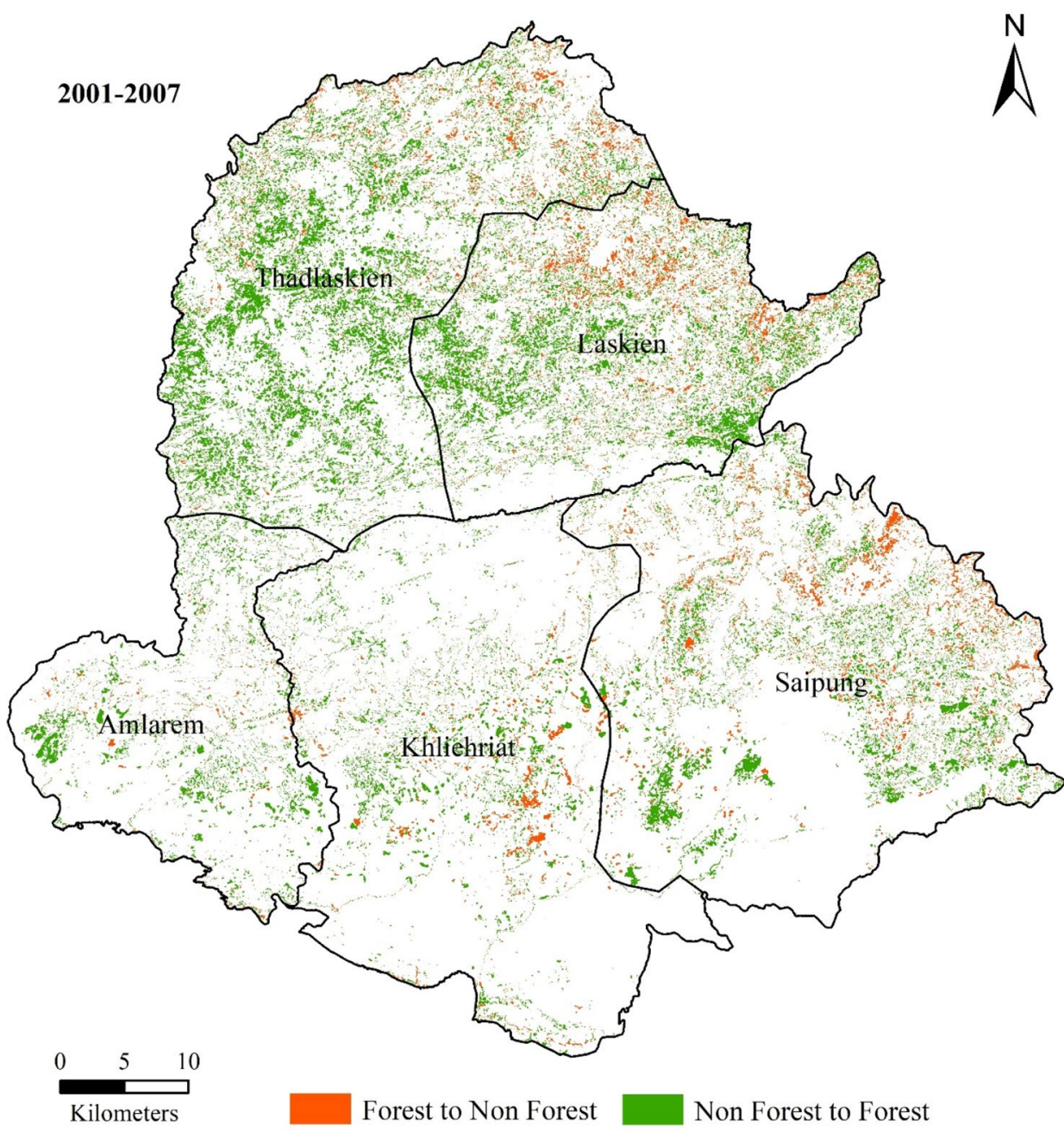

Table 5 Change matrix on land cover between the year 2007 and 2015

\begin{tabular}{|c|c|c|c|c|c|}
\hline \multirow[t]{2}{*}{ Land cover categories } & \multicolumn{5}{|c|}{ 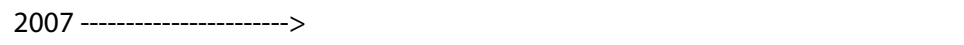 } \\
\hline & Non-forest & Dense forest & Open forest & Scrub forest & Total \\
\hline \multicolumn{6}{|l|}{2015 ----------------->> } \\
\hline Non-forest & 1203.90 & 64.45 & 432.50 & 3.39 & 1704.23 \\
\hline Dense forest & 74.67 & 779.88 & 468.62 & 4.51 & 1327.68 \\
\hline Open forest & 90.95 & 231.97 & 452.31 & 15.37 & 790.61 \\
\hline Scrub forest & 2.66 & 0.30 & 1.78 & 4.34 & 9.08 \\
\hline Total & 1372.18 & 1076.59 & 1355.20 & 27.61 & 3831.60 \\
\hline
\end{tabular}

\subsubsection{Change area-block-wise}

The block-wise changes in area are summarized in Table 7. Change from forest to non-forest area was considered as a negative change and non-forest to forest area as a positive change (Fig. 8). The blocks considered in the present study include Amlarem, Khliehriat, Laskeiñ, Thadlaskeiñ, and Saipung with an area of $398,1280,390.4,896.6$, and $846 \mathrm{~km}^{2}$, respectively. The highest positive change during the periods of 1995-2001 (72.83 $\left.\mathrm{km}^{2}\right)$ and 2001-2007 (171.52 km²) was observed in Thadlaskeiñ block whereas the highest negative changes during the same period were observed in the Saipung block (56.01 and $42.08 \mathrm{~km}^{2}$, respectively). During 2007-2015, the highest positive and negative changes were observed in Thadlaskeiñ $\left(212.01 \mathrm{~km}^{2}\right)$ and Khliehriat $\left(44.79 \mathrm{~km}^{2}\right)$, respectively.

A positive change was apparent in Thadlaskeiñ block with an increased area of $72.83,171.52$, and $212.81 \mathrm{~km}^{2}$ during the period 1995-2001, 2001-2007, and 2007-2015, respectively. This could be due to agro-horticulture 
Fig. 6 Change in forest class map for the year 2007 to 2015

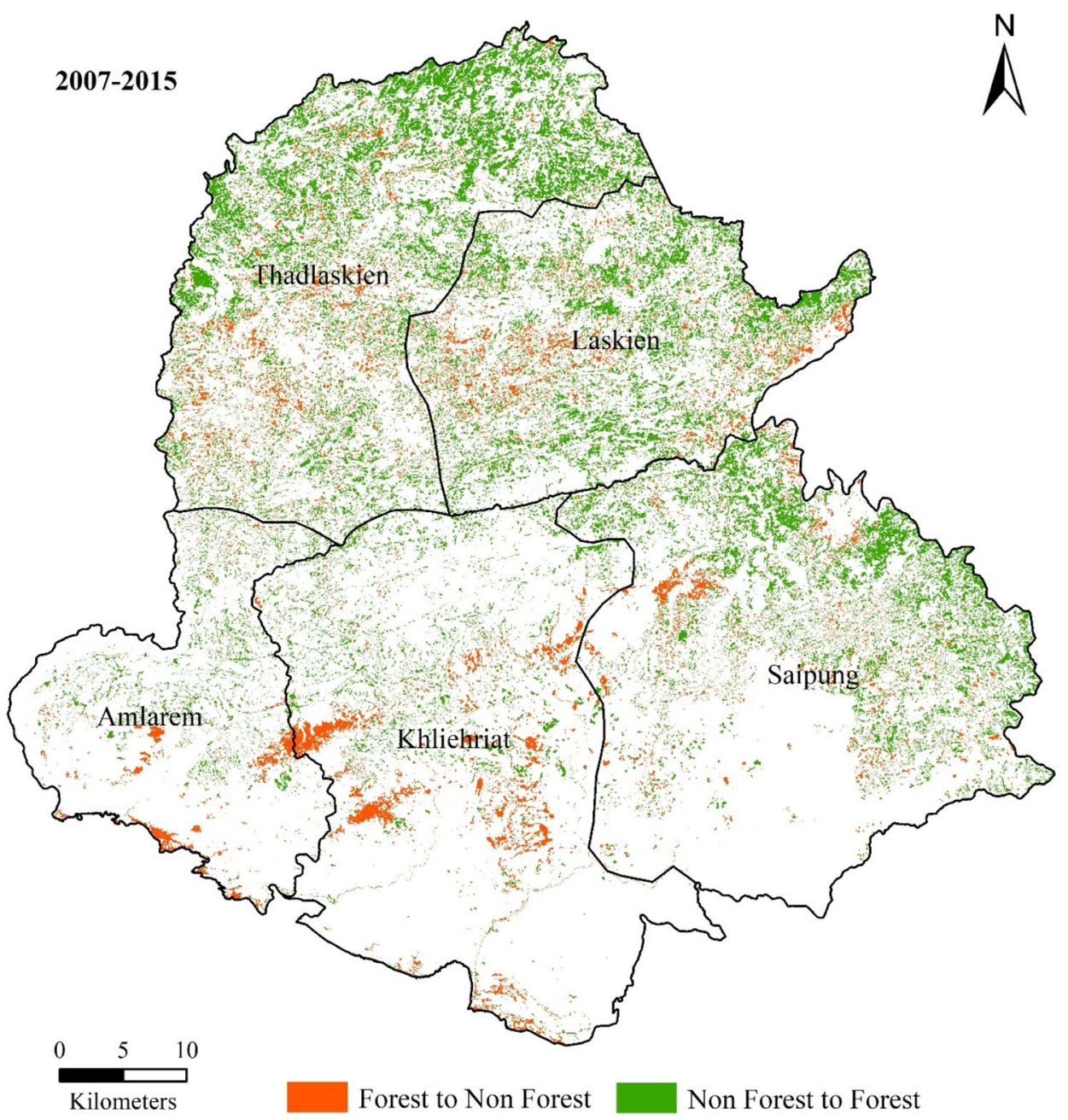

plantation adopted at Saphoh and Larnai village in Thadlaskeiñ block between 2011 and 2016 [57]. Additionally, a similar trend of positive change during the study period was also apparent in Laskeiñ block which can be attributed to horticultural plantations such as oranges around the Raliang area. It is widely adopted by the farmers in the Jaiñtia Hills of Meghalaya, where hill slopes are quite steep with low soil depth. Overall, the highest negative change for the period 1995-2015 was apparent in Khliehriat block can be attributed to the large scale of limestone mining and production activity for cement factories in Jaiñtia Hills.

\subsubsection{Quantification of the spatial pattern of forest fragmentation}

It has been observed that from 1995 to 2007 the number of patches (NP) and patch density (PD) has increased in the dense forest category. The number of patches was observed to be 12600,17032 , and 17950, and patch density was observed to be $1.87,2.53$, and 2.67 , respectively, for the years 1995, 2001, and 2007. This indicates the division of habitats segregated by a matrix of man-made transformed land cover in the past 12 years. After a gap of almost a decade, the number of patches in 2015 decreased to 13940 which signifies an improvement. As per the table, it was observed PLAND was found to be complementary with the class area (CA) which both showed an increase from 1995 to 2007 and a decrease from 2007 to 2015. LPI increased from 1995 to 2007 at a rate of $2.44,11.58$, and $12.97 \%$ in 1995,2001 , and 2007, respectively, and a big decrease of $4.45 \%$ in 2015 . To understand the fragmentation better, the edge density (ED) is another variable to assess. In this case, ED revealed an increase of $20.66 \mathrm{~m} / \mathrm{ha}$ and $31.15 \mathrm{~m} /$ ha, $31.94 \mathrm{~m} /$ ha in 1995, 2001 and 2007, respectively. However, 2015 observed a decrease up to $25.66 \mathrm{~m} / \mathrm{ha}$. This denotes that with more high-value ED there is fragmentation in the spatial extent [58]. Landscape shape index (LSI) is also one of the indices that quantify the complexity of the landscape which measures the total edge that adjusts for the landscape [59]. LSI also indicated the same trend 
Fig. 7 Change in forest class map for the year 1995 to 2015

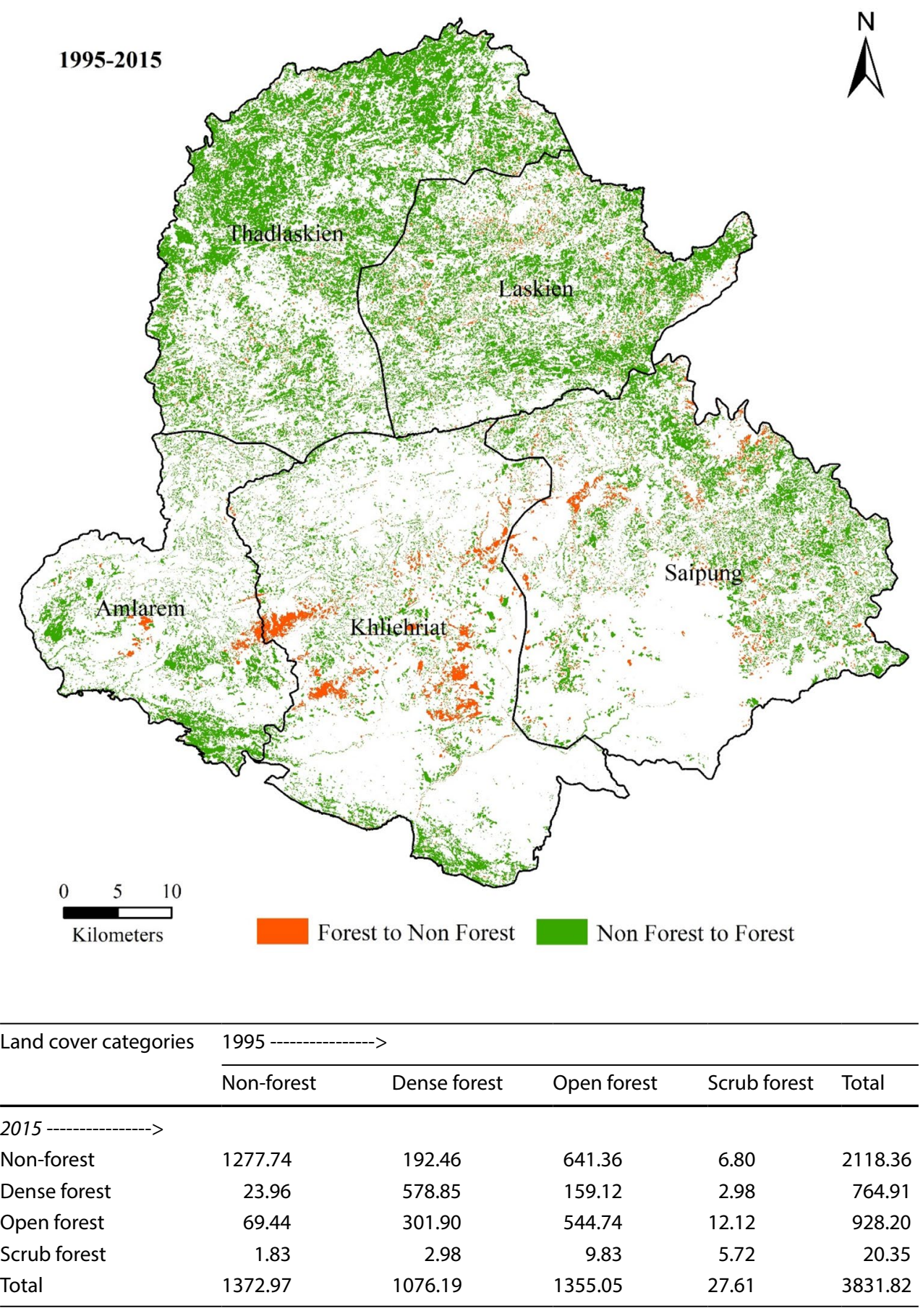

\begin{tabular}{lcccrr}
\hline Land cover categories & \multicolumn{1}{l}{1995 ------------> } & & \\
\cline { 2 - 5 } & Non-forest & Dense forest & Open forest & Scrub forest & Total \\
\hline 2015 -----------> & & & & & \\
Non-forest & 1277.74 & 192.46 & 641.36 & 6.80 & 2118.36 \\
Dense forest & 23.96 & 578.85 & 159.12 & 2.98 & 764.91 \\
Open forest & 69.44 & 301.90 & 544.74 & 12.12 & 928.20 \\
Scrub forest & 1.83 & 2.98 & 9.83 & 5.72 & 20.35 \\
Total & 1372.97 & 1076.19 & 1355.05 & 27.61 & 3831.82 \\
\hline
\end{tabular}

Table 6 Change matrix on land cover between the year 1995 and 2015 increased then decrease, i.e. $125.58,146.97,147.42$ for the years 1995, 2001, and 2007, respectively, and decreased to 131.47 in 2015 . IJ is based on how often the cells along the perimeter of each patch type are adjacent to other patch types. The category of IJI increased from 1995 to 2001, then decreased 2001 onwards and lasted till 2015 $\mathrm{IJI}$. The IJ value of dense forest categories shows a uniform configuration of dense forest (Table 8). However, a decrease in IJ (2001 to 2015) denotes that the dense forest area is less uniform [60]. MESH measures the proportional area of each patch based on the total landscape including background. It was observed that MESH value for dense forest has increased from 1995 to 2001. It covered an area of 703.67 ha in 1995 and 9049.58 ha in 2001, whereas later in 2007 it decreases to 8384.25 ha then it reduced to 1791.19 ha in 2015 . The number of patches and patch density for the open forest category increase, then with time it reduced. The number of patches was 19968, 20360, 
Table 7 Analysis of change area according to the block boundary

\begin{tabular}{|c|c|c|c|c|c|c|c|}
\hline \multicolumn{2}{|l|}{ 1995-2001 } & \multicolumn{2}{|l|}{ 2001-2007 } & \multicolumn{2}{|l|}{$2007-2015$} & \multicolumn{2}{|l|}{ 1995-2015 } \\
\hline Block & Area $\left(\mathrm{km}^{2}\right)$ & Block & Area $\left(\mathrm{km}^{2}\right)$ & Block & Area $\left(\mathrm{km}^{2}\right)$ & Block & Area $\left(\mathrm{km}^{2}\right)$ \\
\hline Amlarem & 62.73 & Amlarem & 42.24 & Amlarem & 45.15 & Amlarem & 84.66 \\
\hline Negative & 14.90 & Negative & 5.05 & Negative & 21.71 & Negative & 7.48 \\
\hline Positive & 47.83 & Positive & 37.18 & Positive & 23.44 & Positive & 77.18 \\
\hline Khliehriat & 95.09 & Khliehriat & 63.55 & Khliehriat & 87.50 & Khliehriat & 140.53 \\
\hline Negative & 34.00 & Negative & 18.04 & Negative & 44.79 & Negative & 40.75 \\
\hline Positive & 61.09 & Positive & 45.50 & Positive & 42.71 & Positive & 99.77 \\
\hline Laskeiñ & 108.58 & Laskeiñ & 136.45 & Laskeiñ & 217.23 & Laskeiñ & 302.04 \\
\hline Negative & 39.22 & Negative & 33.39 & Negative & 34.52 & Negative & 13.75 \\
\hline Positive & 69.35 & Positive & 103.06 & Positive & 182.71 & Positive & 288.28 \\
\hline Saipung & 118.45 & Saipung & 119.52 & Saipung & 226.83 & Saipung & 342.09 \\
\hline Negative & 56.01 & Negative & 42.08 & Negative & 32.40 & Negative & 28.52 \\
\hline Positive & 62.44 & Positive & 77.43 & Positive & 194.43 & Positive & 313.57 \\
\hline Thadlaskeiñ & 108.85 & Thadlaskeiñ & 196.94 & Thadlaskeiñ & 255.18 & Thadlaskeiñ & 411.84 \\
\hline Negative & 36.02 & Negative & 25.42 & Negative & 43.17 & Negative & 8.03 \\
\hline Positive & 72.83 & Positive & 171.52 & Positive & 212.01 & Positive & 403.81 \\
\hline Total & 493.70 & Total & 558.69 & Total & 831.88 & Total & 1281.16 \\
\hline
\end{tabular}

(a)

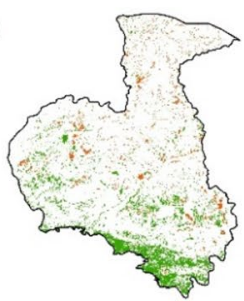

(f)

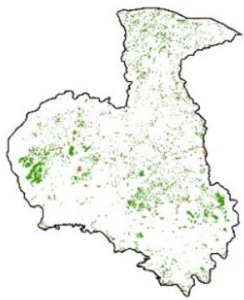

(k)

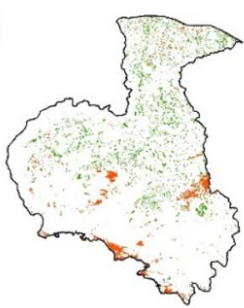

(p)

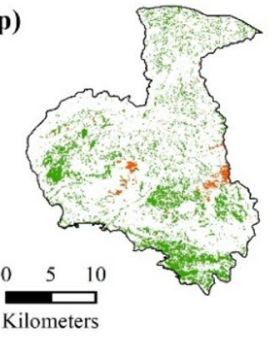

(b)

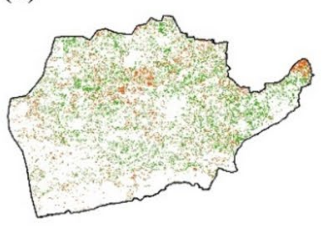

(g)

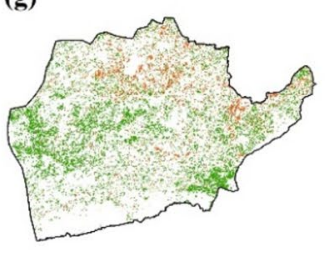

(I)

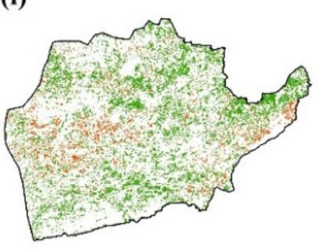

(q)

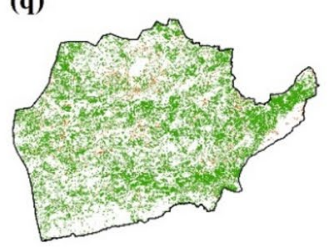

(c)

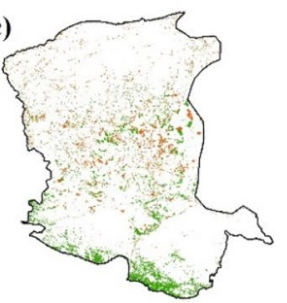

(h)

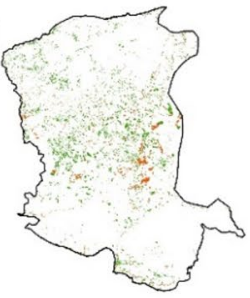

(m)

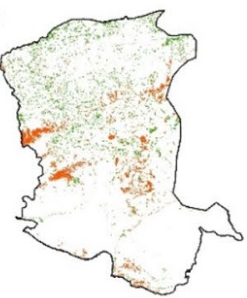

(r)

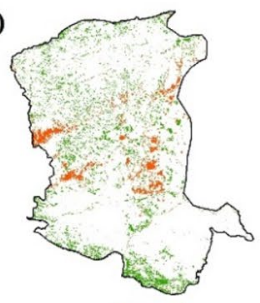

(d)

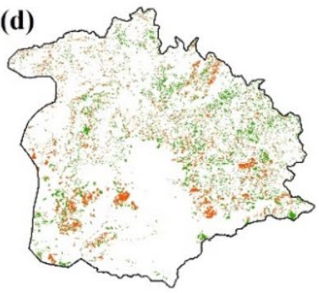

(i)

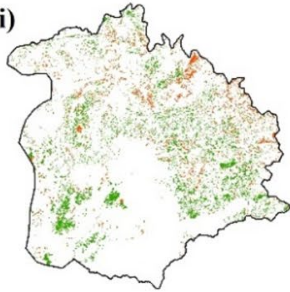

(n)

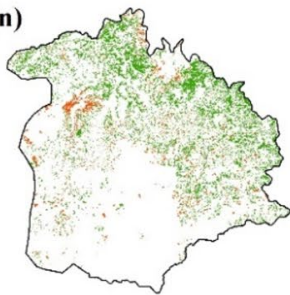

(s)

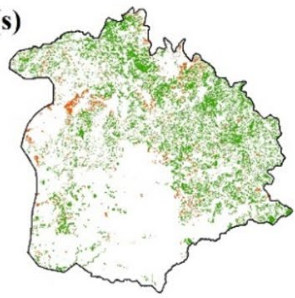

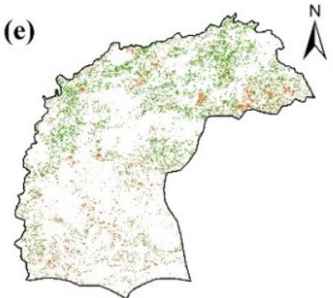

(e)

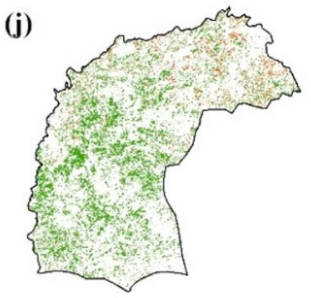

(o)

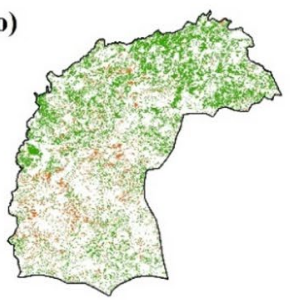

(t)

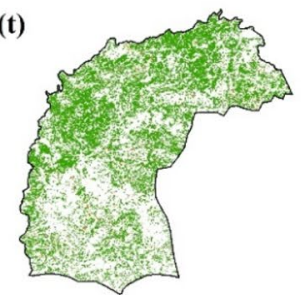

Forest to Non Forest Non Forest to Forest

Fig. 8 Change category maps of (a) Amlarem (b) Laskeiñ (c) Khliehriat (d) Saipung (e) Thadlaskeiñ for 1995-2001: (f) Amlarem (g) Laskeiñ (h) Khliehriat (i) Saipung (j) Thadlaskeiñ for 2001 to
2007: (k) Amlarem (I) Laskeiñ (m) Khliehriat (n) Saipung (o) Thadlaskeiñ for 2007 to 2015: (p) Amlarem (q) Laskeiñ (r) Khliehriat (s) Saipung (t) Thadlaskeiñ for 1995 to 2015 
Table 8 Overview of fragmentation in spatial extent of land cover $(1995,2001,2007$, and 2015)

\begin{tabular}{|c|c|c|c|c|c|c|c|c|c|c|c|}
\hline SI. No. & LULC CLASS & $C A$ & PLAND (\%) & NP & PD & LPI (\%) & $\mathrm{TE}(\mathrm{m})$ & $\mathrm{ED}(\mathrm{m} / \mathrm{ha})$ & LSI & | | | | & MESH (ha) \\
\hline \multicolumn{12}{|l|}{1995} \\
\hline 1 & Scrub forest & 2034.72 & 0.30 & 1455 & 0.22 & 0.02 & 730620 & 1.09 & 40.46 & 55.05 & 0.07 \\
\hline 2 & Open forest & 92827.17 & 13.80 & 19968 & 2.97 & 0.89 & 23859060 & 35.47 & 170.69 & 57.72 & 172.25 \\
\hline 3 & Dense forest & 76497.75 & 11.37 & 12600 & 1.87 & 2.44 & 13893780 & 20.66 & 125.58 & 43.26 & 703.67 \\
\hline 4 & Non-forest & 211806.38 & 31.46 & 6928 & 1.03 & 27.25 & 16347270 & 24.30 & 88.83 & 45.94 & 49985.27 \\
\hline \multicolumn{12}{|l|}{2001} \\
\hline 1 & Scrub forest & 1885.95 & 0.28 & 1318 & 0.20 & 0.014 & 675540 & 1.0043 & 38.82 & 42.66 & 0.042 \\
\hline 2 & Open forest & 55321.38 & 8.22 & 20360 & 3.03 & 0.49 & 16443420 & 38.45 & 174.67 & 55.96 & 43.09 \\
\hline 3 & Dense forest & 126963.9 & 18.88 & 17032 & 2.53 & 11.58 & 20951580 & 31.15 & 146.97 & 54.39 & 9049.58 \\
\hline 4 & Non-forest & 198944.28 & 29.58 & 5787 & 0.86 & 25.55 & 14660460 & 21.80 & 82.16 & 51.62 & 43930.47 \\
\hline \multicolumn{12}{|l|}{2007} \\
\hline 1 & Scrub forest & 908.82 & 0.14 & 1042 & 0.15 & 0.012 & 408360 & 0.61 & 33.86 & 50.66 & 0.02 \\
\hline 2 & Open forest & 79015.86 & 11.75 & 19875 & 2.95 & 1.09 & 19230540 & 34.47 & 171.03 & 54.23 & 172.47 \\
\hline 3 & Dense forest & 132722.55 & 19.73 & 17950 & 2.67 & 12.97 & 21484560 & 31.94 & 147.42 & 51.65 & 8384.25 \\
\hline 4 & Non-forest & 170468.28 & 25.34 & 6384 & 0.95 & 18.56 & 15861600 & 23.58 & 96.03 & 56.31 & 23322.70 \\
\hline \multicolumn{12}{|l|}{2015} \\
\hline 1 & Scrub forest & 2761.47 & 0.41 & 1543 & 0.23 & 0.03 & 892740 & 1.33 & 42.39 & 59.76 & 0.128 \\
\hline 2 & Open forest & 135520.38 & 20.15 & 18980 & 2.82 & 4.55 & 28510980 & 31.39 & 165.56 & 57.52 & 1685.98 \\
\hline 3 & Dense forest & 107659.53 & 16.01 & 13940 & 2.07 & 4.45 & 17259540 & 25.66 & 131.47 & 43.50 & 1791.19 \\
\hline 4 & Non-forest & 137217.89 & 20.37 & 9912 & 1.47 & 14.48 & 17674260 & 26.28 & 119.36 & 40.78 & 14117.82 \\
\hline
\end{tabular}

CA Class area, PLAND Percentage of landscape, NP No. of patches, PD Patch density, LPI Largest patch index, TE Total edge, ED Edge density, LSI Largest shape index, IJI Inter-juxtaposition index, MESH

and 19875 for the years 1995, 2001, and 2007 respective and later reduced to 18980 in 2015. The patch density was found to be $2.97,3.03,2.95$, and 2.82 for the years 1995 , 2001,2007 , and 2015, respectively. This behavioural pattern of NP showed an increase over a period of time and a decrease from 20360 to 18980 during 2001-2015 could be due to patch amalgamation. PLAND decreases from the year 1995 to 2001 whereas increases from 2007 to 2015. From 1995 to 2001 LPI for open forest decreased from 0.89 to $0.49 \%$ and later it increased from 0.49 to $4.55 \%$ during 2001-2015. This depicts an increase due to aggregation of patch type. Edge density increased from 1995 to 2001 and then decreased between 2007 and 2015 possibly due to anthropogenic activities. The decline in NP and ED of open forest could be a diversion of dense forest and non-forest to open forest category. The LSI for the open forest reported an increase from 170.69 to 174.67 during 1995-2001 and a decrease from 174.67 to 165.56 for the period 2001-2015. The increase in LSI indicates open forests had undergone a disaggregation of the patches. Over time, LSI decreased implying an increase in open forest addressing an aggregation of patches under a dominating class which is the open forest category. IJ value seemed to be decreasing from 1995 to 2001 indicating a non-uniform spatial distribution and an increase from 1995 to 2001 denotes uniform spatial distribution. When IJl approaches zero, it indicates the uneven distribution of patches whereas a value of hundred indicates that all the patch types are equally adjacent with other patch types [61, 62]. Based on MESH index, a decrease in 1995 to 2001 from 172.25 to 43.09 ha was apparent along with a significant increase between 2001 and 2015 from 43.09 to 1685.98 ha. While the number of patches (NP) of scrub forest decreased from 1995 to 2007, an increase in 2015 was apparent. A similar pattern has been followed by patch density (PD).

It has been observed that number of patches (NP) decreased from 6928 to 5717 between 1995 and 2001; however, an increase from 6384 to 9912 was apparent between 2007 and 2015. It has also been observed that after a gap of 14 years (2001 to 2015) non-forest indicated an increase in the number of patches with an increase in edge density as $21.8,23.58$, and $26.28 \mathrm{~m} / \mathrm{ha}$, respectively. A higher patch number indicates more edges which shows a greater extent of fragmentation. The number of patches of wasteland, built-up land, croplands, and water bodies has expanded during the studied period. It has been reported that non-forest such as built-up and croplands are the reason for forest degradation $[63,64]$. LSI increased from 82.16 to 119.36 for the year 2001 to 2015 which shows segregation of aggregated patches. MESH value decreased continuously from 49985.27 to 14117.82 over the studied period. LPI of non-forest for all the years 
revealed a decreasing trend, i.e. $27.25,25.55,18.56$, and $14.48 \%$, respectively.

The dense forest and non-forest category are reported to have experienced major disturbances which led to fragmentation. Assessment of forest canopy density and forest fragmentation has been adopted by various studies for analysing the status of forest conditions $[65,66]$. Despite of apparent fragmentation, the increase in forest cover can be attributed to regeneration, afforestation, or secondary forest succession $[67,68]$. The study area is rich in mineral resources, high population of rural and tribal communities which has a high dependence on forest resources for their livelihood, enterprise, and subsistence [69]. Such dependency on forest resources could ultimately lead to more fragmentation in the study area.

It was reported from 1994 to 2014 that the community forests and the reserved forest were more exploited as compared to state forests [70]. India State Forest Report 2015 , outline that the forest cover of India has increased by $5081 \mathrm{~km}^{2}$ with $21.34 \%$ for moderate dense $(21.34 \%)$ whereas $2510 \mathrm{~km}^{2}$ of the very dense forest has been lost [52]. An increase in forest fragmentation is due to anthropogenic activities [71, 72], it is due to the cultivation of paddy, minor fuelwood, and shifting cultivation for turmeric cultivation [73]. The area reported $40 \%$ of rice is cultivated in jhum sites [74] which is detrimental to forests, soil, and biodiversity [75-76]. Moreover, the mining activities are high in the area which ultimately affects the common herbal remedies used by the Jaiñtia tribe community namely Litsea khasiana, Aegle marmelos, Averrhoa carambola, Gaultheria fragrantissima, Gmelia arborea, Nepenthes khasiana, Oroxylum indicum, Rhododendron arborerum, Swertia chirayita, Ficus benghalensis, Taxus baccata, Mimosa pudica, Eupatorium cannabinum, Potentilla fulgens and Rubus ellipticus [77].

\section{Conclusion}

The study reported that dense forest and open forest increased by $8.13 \%$ and $11.14 \%$, respectively, however, $19.47 \%$ of non-forests has decreased during the study period. Specifically, dense forest areas have become more degraded due to anthropogenic activities in this area. Landscape fragmentation has a great impact on the ecological system, e.g. when natural forests areas are confined into smaller size this ultimately disconnects the ecological corridors and results in loss of biodiversity. An increase in the dense forest is apparent from the temporal land cover change analysis; however, a significant amount of fragmentation has also been observed. Similarly, over the years fragmentation was also observed in the non-forest category accounting for $19.45 \%$ of its spatial extent. This region of interest implies that it has been experiencing land cover changes with more activity resulting in fragmentation. The landscape of Jaiñtia Hills is under pressure due to the local population which is highly dependent on agriculture, coal, and cement industry. The study suggests to curb the intensification of forest cover lost in the study area. The conclusion drawn from this study is that the pattern of forest cover change and forest fragmentation is unpredictable which may be due to the complexity of the landscape structure. Hence, it is crucial to understand the pattern of land cover dynamics and its fragmentation to sustain biological diversity. The outcome will help in redefining ecological zones to maintain the overall spatial composition and configuration of the habitat.

Declarations

Conflict of interest The authors declare that they have no conflict of interest.

Open Access This article is licensed under a Creative Commons Attribution 4.0 International License, which permits use, sharing, adaptation, distribution and reproduction in any medium or format, as long as you give appropriate credit to the original author(s) and the source, provide a link to the Creative Commons licence, and indicate if changes were made. The images or other third party material in this article are included in the article's Creative Commons licence, unless indicated otherwise in a credit line to the material. If material is not included in the article's Creative Commons licence and your intended use is not permitted by statutory regulation or exceeds the permitted use, you will need to obtain permission directly from the copyright holder. To view a copy of this licence, visit http://creativeco mmons.org/licenses/by/4.0/.

\section{Appendix 1}

See Table 9.

Table 9 Administrative blocks of Jaiñtia Hills, Meghalaya, India

\begin{tabular}{llll}
\hline Name of the blocks & Area $\left(\mathrm{km}^{2}\right)$ & Headquarter & $\begin{array}{l}\text { District of Jaiñtia } \\
\text { Hills }\end{array}$ \\
\hline Khliehriat & 1280 & Khliehriat & East Jaiñtia Hills \\
Saipung & 846 & & \\
Amlarem & 398 & Jowai & West Jaiñtia Hills \\
Thadlaskeiñ & 896.6 & & \\
Laskeiñ & 390.4 & & \\
\hline
\end{tabular}




\section{Appendix 2}

See Table 10.

Table 10 Description of satellite data used for the present study

\begin{tabular}{lllll}
\hline $\begin{array}{l}\text { Satellite/ } \\
\text { Sensor }\end{array}$ & Date of image acquisition & Path/Row & Bands used & Spatial Resolution (m) \\
\hline Landsat 5/TM & 19 March 1995 & $136 / 42$ & B1, B2, B3, B4 & 30 \\
& & $136 / 43$ & \\
& 19 March 2001 & $136 / 42$ & B1, B2, B3, B4 & \\
& & $136 / 43$ & \\
& 20 March 2007 & $136 / 42$ & B1, B2, B3, B4 \\
& & $136 / 43$ & \\
Landsat 8/OLI & 10 March 2015 & $136 / 42$ & B1, B2, B3, B4, B5 & \\
& & $136 / 43$ & & \\
\hline
\end{tabular}

\section{Appendix 3}

See Table 11.

Table 11 Description of land use/land cover class

\begin{tabular}{ll}
$\begin{array}{l}\text { Land use/land } \\
\text { cover classes }\end{array}$ & Description of the classes \\
\hline $\begin{array}{l}\text { Dense forest } \\
\text { Open forest }\end{array}$ & $\begin{array}{l}\text { Tree species with canopy over more than } 40 \% \\
\text { Tree species with canopy over more than } 10 \% \\
\text { and less than } 40 \%\end{array}$ \\
$\begin{array}{l}\text { Scrub forest } \\
\text { Non-forest }\end{array}$ & $\begin{array}{l}\text { Wegraded forest land with canopy less than } 10 \% \\
\text { Wasteland, built-up, cropland, water bodies }\end{array}$ \\
\hline
\end{tabular}

\section{Appendix 4}

See Table 12.

Table 12 Types of metrics level

\begin{tabular}{ll}
\hline Metrics level & Description \\
\hline Patch level metrics & Size, shape, and distance to neighbouring patches of an individual patch area quantified at the patch level \\
Class level metrics & $\begin{array}{l}\text { Use these values for all the patches in the same LULC type to give a value for the entire class in the landscape. } \\
\text { Provide unique values without reference to individual patches or classes as they aggregate the properties for } \\
\text { all the patches in the landscape }\end{array}$ \\
\hline
\end{tabular}




\title{
Appendix 5
}

\author{
See Table 13.
}

Table 13 List of landscape metrics used

\begin{tabular}{|c|c|c|}
\hline Metrics & Description & Units \\
\hline Class area & Tells about how much landscape is comprised of a particular patch type & ha \\
\hline Percentage of landscape & $\begin{array}{l}\text { PLAND equals the percentage of the landscape comprised of the corresponding patch } \\
\text { type. }\end{array}$ & $\%$ \\
\hline Number of patches & NP equals the number of patches of the corresponding patch type (class). & No unit \\
\hline Patch density & Ratio of number of patches and the area & per unit per ha \\
\hline Largest patch index & LPI equals the percentage of the landscape comprised by the largest patch & ha \\
\hline Total edge & $\begin{array}{l}\text { TE equals the sum of the lengths }(\mathrm{m}) \text { of all edge segments involving the corresponding } \\
\text { the patch type. }\end{array}$ & $\mathrm{m}$ \\
\hline Edge density & $\begin{array}{l}\text { ED equals the sum of the lengths }(\mathrm{m}) \text { of all edge segments involving the corresponding } \\
\text { patch type, divided by the total landscape area }\left(\mathrm{m}^{2}\right) \text {, multiplied by } 10,000 \text { (to convert } \\
\text { to hectares). }\end{array}$ & $\mathrm{m} / \mathrm{ha}$ \\
\hline Landscape shape index & $\begin{array}{l}\text { Complexity of the landscape that measures the total edge that adjusts for the land- } \\
\text { scape. }\end{array}$ & No unit \\
\hline Interspersion juxtaposition index & $\begin{array}{l}\text { IJI is based on patch adjacency. It is the arrangement of patches on the basis of compo- } \\
\text { sition and configuration in the landscape. }\end{array}$ & No unit \\
\hline Effective mesh size & $\begin{array}{l}\text { MESH measures the proportional area of each patch based on total landscape including } \\
\text { background. }\end{array}$ & ha \\
\hline
\end{tabular}

\section{References}

1. www.intechopen.com

2. Das Gupta S (1999) Studies on vegetal and microbiological processes in coal mining affected areas. Ph.D. Thesis. North_Eastern Hill University, Shillong. India.

3. www.megdmg.gov.in

4. Nandy S, Kushwaha SPS, Dadhwal VK (2011) Forest degradation assessment in the upper catchment of the river Tons using remote sensing and GIS. Ecol Indic 11:509-513. https://doi.org/ 10.1016/j.ecolind.2010.07.006

5. Ramachandra TV, Krishnadas G, Setturu B, Kumar U (2012) Regional bioenergy planning for sustainability in Himachal Pradesh, India. J Energy Environ Carbon Credits 2:13-49

6. O'Neill RV, Krummel JR, Gardner RH et al (1988) Indices of landscape pattern. Landscape Ecol 1:153-162. https://doi.org/10. 1007/BF00162741

7. Turner MG (1990) Spatial and temporal analysis of landscape patterns. Landscape Ecol 4:21-30. https://doi.org/10.1007/ BF02573948

8. Li H, Reynolds JF (1993) A new contagion index to quantify spatial patterns of landscapes. Landscape Ecol 8:155-162. https:// doi.org/10.1007/BF00125347

9. McGarigal K, Marks BJ (1995) FRAGSTATS: spatial pattern analysis program for quantifying landscape structure. Gen. Tech. Rep. PNW-GTR-351. Portland, OR: US Department of Agriculture, Forest Service, Pacific Northwest Research Station. 122 pp. 351.

10. Gustafson EJ (1998) Quantifying landscape spatial pattern: what is the state of the art? Ecosystems 1:143-156. https://doi.org/10. $1007 / \mathrm{s} 100219900011$

11. He HS, DeZonia BE, Mladenoff DJ (2000) An aggregation index (Al) to quantify spatial patterns of landscapes. Landscape Ecol 15:591-601. https://doi.org/10.1023/A:1008102521322
12. McGarigal K, Cushman SA, Neel MC, Ene E (2002) FRAGSTATSv3: spatial pattern analysis program for categorical maps.

13. www.cgwb.gov.in/District_Profile/Meghalaya/Jaintia.

14. http://shodhganga.inflibnet.ac.in/bitstream/

15. Census of India (2011) Blocks in Jaintia hills district, Meghalaya.

16. Mickelson JG, Civco D, Silander J (1998) Delineating forest canopy species in the Northeastern United States using multi-temporal TM imagery. PhotogrammEng Remote Sens 64:891-904

17. Franklin J, Logan TL, Woodcock CE, Strahler AH (1986) Coniferous forest classification and inventory using Landsat and digital terrain data. IEEE T Geosci Remote Sens 24:139-149. https://doi. org/10.1109/TGRS.1986.289543

18. Lee JK, Park RA, Mausel PW (1992) Application of geoprocessing and simulation modeling to estimate impacts of sea level rise on the northeast coast of Florida. PhotogrammEng Remote Sens 58:1579-1586

19. Clark ML, Roberts DA, Clark DB (2005) Hyperspectral discrimination of tropical rain forest tree species at leaf to crown scales. Remote Sens Environ 96:375-398. https://doi.org/10.1016/j.rse.2005.03.009

20. Butera MK (1983) Remote sensing of wetlands. IEEE T Geosc Remote Sens 21:383-392. https://doi.org/10.1109/TGRS.1983. 350471

21. Yi GC, Risley D, Koneff M, Davis C (1994) Development of Ohio's GIS-based wetlands inventory. J Soil Water Conserv 49:23-28

22. Turner MG (2005) Landscape ecology: what is the state of the science? Ann Rev EcolEvolSyst 36:319-344

23. Turner MG, Gardner RH, O'neill RV (2001) Landscape ecology in theory and practice Springer. pp. 406.

24. Turner MG (1989) Landscape ecology: the effect of pattern on process. Annu Rev Ecol Syst 20:171-197. https://doi.org/10. 1146/annurev.es.20.110189.001131

25. Urban DL, O'Neill RV, Shugart HH (1987) Landscape Ecology: A hierarchical perspective can help scientists understand spatial 
patterns. Bioscience 37:119-127. https://doi.org/10.2307/13103 66

26. Riitters $\mathrm{KH}$, O'neill RV, Hunsaker $\mathrm{CT}$, Wickham JD, Yankee $\mathrm{DH}$, Timmins SP, Jones KB, Jackson BL (1995) A factor analysis of landscape pattern and structure metrics. Landscape Ecol 10:2339. https://doi.org/10.1007/BF00158551

27. Herzog F, Lausch A (2001) Supplementing land-use statistics with landscape metrics: some methodological considerations. Environ Monit Assess 72:37-50. https://doi.org/10.1023/A:10119 49704308

28. Zheng D, Wallin DO, Hao Z (1997) Rates and patterns of landscape change between 1972 and 1988 in the Changbai Mountain area of China and North Korea. Landsc Ecol 12:241-254. https://doi.org/10.1023/A:1007963324520

29. Wei L, Luo Y, Wang M, Su S, Pi J, Li G (2020) Essential fragmentation metrics for agricultural policies: Linking landscape pattern, ecosystem service and land use management in urbanizing China. Agric Syst 182:102833

30. Gabril EMA, Denis DM, Nath S, Paul A, Kumar M (2019) Quantifying LULC change and landscape fragmentation in Prayagraj district, India using geospatial techniques. Pharma Innov J 8(5):670-675

31. Mahato LL, Kumar M, Kumar J, Nath S, Lal D (2021) Forest changes and fragmentation analysis of Hazaribagh district of Jharkhand, India using Geospatial technology. Pharma Innov J SP-10(1):222-227

32. Singh SK, Laari PB, Mustak SK, Srivastava PK, Szabó S (2018) Modelling of land use land cover change using earth observation data-sets of Tons River Basin, Madhya Pradesh. India. Geocarto Int 33(11):1202-1222

33. Cushman SA, McGarigal K, Neel MC (2008) Parsimony in landscape metrics: strength, universality, and consistency. Ecol Indic 8:691-703. https://doi.org/10.1016/j.ecolind.2007.12. 002

34. Linke J, Franklin SE (2006) Interpretation of landscape structure gradients based on satellite image classification of land cover. Can J Remote Sens 32:367-379. https://doi.org/10.5589/ m06-031

35. Griffith JA, Martinko EA, Price KP (2000) Landscape structure analysis of Kansas at three scales. Landsc Urban Plan 52:45-61. https://doi.org/10.1016/S0169-2046(00)00112-2

36. Hargis CD, Bissonette JA, David JL (1998) The behavior of landscape metrics commonly used in the study of habitat fragmentation. Landscape Ecol 13:167-186. https://doi.org/10.1023/A: 1007965018633

37. Cain DH, Riitters K, Orvis K (1997) A multi-scale analysis of landscape statistics. Landscape Ecol 12:199-212. https://doi.org/10. 1023/A:1007938619068

38. Lamine S, Petropoulos GP, Singh SK, Szabó S, Bachari NEI, Srivastava PK, Suman S (2018) Quantifying land use/land cover spatio-temporal landscape pattern dynamics from Hyperion using SVMs classifier and FRAGSTATS. Geocarto Int 33:862-878. https://doi.org/10.1080/10106049.2017.1307460

39. Van Strien MJ, Slager CTJ, de Vries B, Grêt-Regamey A (2016) An improved neutral landscape model for recreating real landscapes and generating landscape series for spatial ecological simulations. Ecol Evol 6:3808-3821. https://doi.org/10.1002/ ece 3.2145

40. Prastacos P, Lagarias A (2016) An analysis of the form of urban areas in Europe using spatial metrics. AGILE.

41. Schumaker NH (1996) Using landscape indices to predict habitat connectivity. Ecol 77(4):1210-1225

42. Neel MC, McGarigal K, Cushman SA (2004) Behavior of classlevel landscape metrics across gradients of class aggregation and area. Landscape Ecol 19(4):435-455
43. Cardille J, Turner M, Clayton M, Gergel S, Price S (2005) METALAND: characterizing spatial patterns and statistical context of landscape metrics. AIBS Bulletin 55(11):983-988

44. Linke J, McDermid GJ, Pape AD, McLane AJ, Laskin DN, HallBeyer M, Franklin SE (2009) The influence of patch-delineation mismatches on multi-temporal landscape pattern analysis. Landscape Ecol 24(2):157-170

45. www.umass.edu

46. Singh SK, Srivastava PK, Szabó S, Petropoulos GP, Gupta M, Islam $\mathrm{T}$ (2017) Landscape transform and spatial metrics for mapping spatiotemporal land cover dynamics using Earth Observation data-sets. Geocarto Int 32(2):113-127. https://doi.org/10.1080/ 10106049.2015.1130084

47. Jensen JR (1996) Introductory digital image processing prenticehall. Englewood Cliffs, NJ.

48. MECOFED (2011) Jaintia Hills District.

49. www.indiastat.com

50. Sarma K (2005) Impact of coal mining on vegetation: a case study in Jaintia Hills district of Meghalaya, India. M.Sc. Thesis. Faculty of Geo-Information Science and Earth Observation (ITC), Netherlands. pp. 1-85.

51. www.fsi.nic.in

52. India State of Forest Report (ISFR) (2015) Forest Survey of India, Ministry of Environment Forest \& Climate Change, Government of India.

53. www.livemint.com

54. www.downtoearth.org.in

55. Ramachandra TV, Bharath S, Bharath A (2014) Spatio-temporal dynamics along the terrain gradient of diverse landscape. J Environ Eng Landscape Manage 22:50-63. https://doi.org/10.3846/ 16486897.2013.808639

56. Schmidt H, Glaesser C (1998) Multitemporal analysis of satellite data and their use in the monitoring of the environmental impacts of open cast lignite mining areas in Eastern Germany. Int J Remote Sens 19:2245-2260. https://doi.org/10.1080/01431 1698214695

57. www.megsoil.gov.in

58. Laurance WF, Nascimento HE, Laurance SG, Andrade A, Ewers RM, Harms KE, Luizao RC, Ribeiro JE (2007) Habitat fragmentation, variable edge effects, and the landscape-divergence hypothesis. PLoS One 2:1-8. https://doi.org/10.1371/journal. pone.0001017

59. Mansour M, Hochschild V, Schultz A, NkuoKuma J (2016) Fragmentation rate and landscape structure of the Tillabry landscape (Sahel region) with reference to desertification. J Geogr Reg Plann 9:77-86. https://doi.org/10.5897/jgrp2015.0538

60. Herzog F, Lausch A (2001) Supplementing land-use statistics with landscape metrics: some methodological considerations. Environ Monit Assess 72:37-50. https://doi.org/10.1023/A:10119 49704308

61. McGarigal K, Marks BJ (1994) Spatial pattern analysis program for quantifying landscape structure. Dolores (CO): PO Box, 606, pp. 67.

62. Kumar M, Denis DM, Singh SK, Szabó S, Suryavanshi S (2018) Landscape metrics for assessment of land cover change and fragmentation of a heterogeneous watershed. Remote Sens Appl Soc Environ 10:224-233. https://doi.org/10.1016/j.rsase. 2018.04.002

63. Southworth J, Munroe D, Nagendra H (2004) Land cover change and landscape fragmentation-comparing the utility of continuous and discrete analyses for a western Honduras region. Agr Ecosyst Environ 101:185-205. https://doi.org/10.1016/j. agee.2003.09.011

64. Lepers E, Lambin EF, Janetos AC, DeFries R, Achard F, Ramankutty $\mathrm{N}$, Scholes RJ (2005) A synthesis of information on rapid landcover change for the period 1981-2000. Bioscience 55:115-124. 
https://doi.org/10.1641/0006-3568(2005)055[0115:ASOIOR]2.0. $\mathrm{CO} ; 2$

65. Mon MS, Kajisa T, Mizoue N, Yoshida S (2010) Monitoring deforestation and forest degradation in the Bago Mountain Area, Myanmar using FCD Mapper. J For Plan 15:63-72. https://doi. org/10.20659/jfp.15.2_63

66. Biradar CM, Saran S, Raju PLN, Roy PS (2005) Forest canopy density stratification: How relevant is biophysical spectral response modelling approach? Geocarto Int 20:15-21. https://doi.org/10. 1080/10106040508542332

67. Aerts R, Honnay O (2011) Forest restoration, biodiversity and ecosystem functioning. BMC Ecol 11:29. https://doi.org/10. 1186/1472-6785-11-29

68. Haddad NM, Brudvig LA, Clobert J, Davies KF, Gonzalez A, Holt RD, Lovejoy TE, Sexton JO, Austin MP, Collins CD, Cook WM et al (2015) Habitat fragmentation and its lasting impact on Earth's ecosystems. Sci Adv 1:1-9. https://doi.org/10.1126/sciadv.15000 52

69. Tynsong H, Tiwari BK, Dkhar M (2012) Contribution of NTFPs to cash income of the War Khasi community of southern Meghalaya, North-East India. For Stud China 14:47-54. https://doi.org/ 10.1007/s11632-012-0104-7

70. Goswami R, Mariappan M, Singh TS, Ganesh T (2016) Conservation effectiveness across state and community forests: the case of Jaintia Hills, Meghalaya, India. Curr Sci 111:380-387. https:// doi.org/10.18520/cs/v111/i2/380-387
71. Malhi Y, Gardner TA, Goldsmith GR, Silman MR, Zelazowski P (2014) Tropical forests in the Anthropocene. Annu Rev Environ Resour 39:125-159. https://doi.org/10.1146/annurev-envir on-030713-155141

72. Barlow J, Lennox GD, Ferreira J, Berenguer E, Lees AC, Mac Nally $\mathrm{R}$, Thomson JR, de Barros Ferraz SF, Louzada J, Oliveira VHF, Parry L et al (2016) Anthropogenic disturbance in tropical forests can double biodiversity loss from deforestation. Nature 535:144147. https://doi.org/10.1038/nature18326

73. Jeeva SRDN, Laloo RC, Mishra BP (2006) Traditional agricultural practices in Meghalaya, North East India. Indian J Tradit Knowl $5: 7-18$

74. www.westjaintiahills.gov.in

75. Malik B (2003) The "problem" of shifting cultivation in the Garo Hills of North-East India, 1860-1970. Conserv Soc 1:287-315

76. Shimrah T, Sarma K, Varga OG, Szilard S, Singh SK (2019) Quantitative assessment of landscape transformation using earth observation datasets in Shirui Hill of Manipur. India. Remote Sens Appl Soc Enviro 15:100237. https://doi.org/10.1016/j.rsase. 2019.100237

77. Kayang $H$ (2007) Tribal knowledge on wild edible plants of Meghalaya. Northeast India. Indian J Tradit Knowl 6(1):177-181

Publisher's Note Springer Nature remains neutral with regard to jurisdictional claims in published maps and institutional affiliations. 